\title{
The Neanderthal Art from Brunique Cave. Becaming Human an Inhuman Creation
}

\author{
Santiago Wolnei Ferreira Guimarães* \\ Federal University of Pará - Anthropology Graduate Program, Brazil
}

Submission: March 05, 2017; Published: July 11, 2017

*Corresponding author: Santiago Wolnei Ferreira Guimarães, Federal University fo Pará - Anthropology Graduate Program, Instituto de Filosofia e Ciências Humanas - IFCH, Rua Augusto Corrêa, 01 - Campus Universitário do Guamá. ZIP: 66075-900, Belém - Pará, Brazil,

Email: santiago.wolnei@gmail.com

\section{Short Communication}

In May 2016, a great discovery brought to light the rearmost evidence about art ever made. The circular structure made with stalagmites and fragments of stalactites fallen to the ground of Brunique Cave, in France, was interpreted as the oldest art ever registered, made 176,000 years ago [1].

This kind of discovery, although apparently another source in order to think of the birth of symbolic thought and also in other dimensions of the mind, which include the aesthetic world, revealed a new problem. In the primordial truth, this problem is constituted as a paradigm perhaps not yet systematized by most scientists involved in such discovery.

The very early age found, together with its insertion within the continental local context, guides all the problems not relative to one of our creations, but indeed, to other species: the Homo neanderthalensis. In this sense, how to make something in short, human, thus made by a being not absolutely human?

The problem is dense and deep, because art would involve categories of thought beyond an event resulting from purely technical nature and manipulation of surroundings. It would be rather, a phenomenon arisen from inside and exposed before our eyes, ears, mouths and hands, not just in accordance with each culture and its rituals, but also according to each individual.

The prospects that deal with prehistoric art as a means of communication are growing [2-8]. Thus, this term has been used in prehistoric studies as a designation employed, in order to characterize moments and social systems, in other words, an approach useful for thinking about archaeological style [9]. According with such a premise, art as reference to aesthetical world could not be thought of for the prehistoric period, taking into account that it would only be born in the Renaissance, as an "awareness of individuality" [10].

This idea is important because it treats the first visual manifestations imprinted on the rock as a direct product of a specific system of meaning, responsible for operating as a mean for social memory recording, as thought by Leroi-Gourhan [11] fifty years ago. Furthermore, it is also useful to refer us to a way of life in which the group actions were more important for survival than the individual ones. However, this makes us think of a limited human being and devoid of cognitive abilities with regard to the creation and aesthetic sensitivity, unless he has developed under more recent cultural bases.

Such assertions lead us to wonder if the arisen of an aesthetic perception would necessarily be subject to some particular socio-cultural context. However, we should wonder if such perceptions would not be also proper of a subject brain to feel the world around it and recreate it according to its need. And will this be the most appropriate term for the phenomenon related to art: the need?

Maybe these findings do not answer to the question, but rather bring paths to think about the problem by researchers, who presented to the world the "Neanderthal art" of Brunique: "What did they do this for?"

Does this side of the mind - the awareness, the reason - be more appropriate as a way to respond to this? Should there be a necessary condition of functionality for such an "artistic" creation? Perhaps not, provided we can think of the mind side not subject to such rules: the unconscious.

The relation between the unconscious and the aesthetic attitude is direct, since it is known that such an attitude isolates the object, not considering in their causes, effects and consequences, but for yourself, while it is pleasant or unpleasant (Stolnitz apud Talon-Hugon). It constitutes, in fact, as an active perception that puts in alert the imagination and the emotions of an intense awareness, attentive to details and the internal organization of the thing. Notwithstanding, from such emotions, a bridge is created to conceive another mental intensity, this time characterized by a primary instinct, in other words, the unconscious, as thought by Freud. 
Once being, the "Neanderthal art", an unconscious phenomenon, it is urgent to ask how it was possible to identify it by us, the Homo sapiens. What would have made a uniquely human category of apprehension and construction of reality be recognized in a different neuro-systemic apparatus? Would it be a misunderstanding of our interpretive abilities? Or in fact, an interpretation based on a convergence of traces relative to the psychic universe, developed very similarly in other species of the genus Homo? The question, being still unanswered, shows dependent upon problems related to the study of signs. As shown by Charles Sanders Pierce, the symbol can be only recognized by the members of the group that created it. However, symbol may be present in all kinds of sign (Including non-arbitrary signs, icons and indexes), making it impossible for interpretations driven by an external observer to these systems, like an archaeologist, who tries to interpret the "history" supposedly present in the drawings represented in the rock. In this way, if the interpretation of the conscious sign proves to be difficult, how much then would the interpretation of an unconscious sign be?

When Freud published his text in 1915 [12], he presents us with the possibility of thinking about the communication between two unconscious persons. But, he might not have imagined the possibility of a non-human unconscious, and even less in the communication between this kind of unconscious and ours.

Obviously, considering the Neanderthal a "not human" requires a lot of care. Although in terms of morphology, the Neanderthals constitute an extinct hominid group known more clearly demarcated, being considered by many a specific species, it has been increasingly difficult to know what are the limits of demarcation, in genetic terms [13-19]. Genetic research has demonstrated the relation between Modern humans and Neanderthals [20]. However, they have been appointed only 04\% of the DNA of European human corresponding to the Neanderthal [21]. Therefore, although it can be clearly stated the existence of gene flow between these two groups, it can be conceived a hybridization as a highly unusual practice among them [22]. This fact confirms the conclusion based on morphological analysis, which indicates the Neanderthal as a distinct species in comparison to Homo sapiens.

The discovery opens a window, in order to think about the possibilities of interaction between two organisms, which although they are very similar, belong to different species. On the other hand, this makes it possible to think about the different forms of communication, conscious as well as unconscious, established not only between humans, but also between these and other living beings [23,24].

Perhaps in this bias, it would be possible to ask whether the signs determined by a more abstract systematization, such as circles formed by stalactites, would have a more universal understanding, or could they only be understood under the pillars of a given culture.

More and more we approach ourselves from the "other". This time, this other is not confined only as a subject coming from a different culture of Western, but more as a subject a little further away, who grew up and developed itself on the other side of the mountain, on "the other side of the river".

This era of technological nomadization, has been emphasized in the conversation about the search for other planets, habitable or not. The interaction occurred more intensely in prehistoric times is once again present. Meanwhile, we asked ourselves how the communication between beings arisen in ecosystems different from those observe in our planet would be. This is the importance of the discussion that is intended to be presented here.

A problem that is addressed when admitting a future interaction between human and non-human, in this case extraterrestrial, finds similar relationship to the past, through the interactions occurred between human and non-human (or almost human, as it could also be said by some), in this case Neanderthals. Hence, the importance for knowledge brought by anthropology and by man's past: is when he knows more about himself, he tries to indicate similar reality constructs and intentions to "others". It remains to be seen the limits to believe in such constructions. Maybe they are even possible. Why not?

\section{References}

1. Jaubert J, Verheyden S, Genty D, Soulier M, Cheng H, et al. (2016) Early Neanderthal constructions deep in Bruniquel Cave in southwestern France. Nature 534 (7605): 111-114.

2. Conkey M (1990) Experimenting with style and archaeology: some historical and theoretical issues In: The Uses of Style in Archaeology. In: Conkey M \& Hastorf C (Eds.), New Directions in Archaeology series. Cambridge University Press, Cambridge, London, UK, pp. 5-17.

3. Sackett J (1986) Style, function, and assemblage variability: a replay to Binford. American Antiquity 51(3): 628-634.

4. Sackett J (1990) Style and ethnicity in archaeology: The case for isochrestism. In: Conkey M \& Hastorf C (Eds.), The Uses of Style in Archaeology. Cambridge University Press, Cambridge, London, UK, p.32-43.

5. Sauvet G (1988) La communication graphique paléolithique (de l'analyse quantitative d'un corpus de données à son interprétation sémiologique). L' Anthropologie 92(1): 3-16.

6. Sauvet G (1990) Les signes dans l'art mobilier. L'art des objets au Paléolithique, Colloque de Foix 1987. Les voies de la Recherche, p. 8399.

7. Sauvet G, Wlodarczyk A (1977) Essai de sémiologie préhistorique: pour une théorie des premiers signes graphiques de l'homme In : Bulletin de la Société préhistorique française, tome 74: Etudes et Travaux, fascicule 2 .

8. Sauvet G, Wlodarczyk A (2008) Towards a Formal Grammar of the European Palaeolithic Cave Art. Rock Art Research. The Journal of the Australian Rock Art Research Association (AURA) 25(2): 165-172.

9. Wiessner P (1989) Is there a unity to style? In: The Uses of Style in Archaeology. In: Conkey M \& Hastorf C (Eds.), New Directions in 
Archaeology series. Cambridge University Press, Cambridge, London, UK, pp. 105-112.

10. Baldellou V (2001) Semiologia y semiótica en la interpretación del arte post-paleolítico In: Semiótica del arte prehistórico. Servicio de Estudios Arqueológicos Valencianos. Série Arqueológica. Valencia: Diputación Provincial de Valencia 18: 25-51.

11. Leroi-Gourhan A (1965) Le geste et la parole - la mémoire et les rythmes. Editions Albin Michel.

12. Freud S (1915) The Unconscious. In: The Standard Edition of the Complete Psychological Works of Sigmund Freud, Volume XIV (19141916): On the History of the Psycho-Analytic Movement, Papers on Met psychology and Other Works, p.159-215.

13. Benazzi S, Douka K, Fornai C, Bauer C, Kullmer, O, et al. (2011) Early dispersal of modern humans in Eurupe and implications for Neanderthal behavior. Nature 479(7374): 525-528.

14. Stringer C, Gamble C (1993) In search of the Neanderthals. Thames and Hudson, PP 247.

15. Harvati K (2015) Neanderthals and their contemporaries. In: Henke, W Tattersall I (eds.) Handbook of Paleoanthropology. ( $2^{\text {nd }}$ edn), Springer, USA, pp. 2243-2279.

16. Harvati, K, Frost S, Mcnulty K (2004) Neanderthal taxonomy reconsidered: implications of $3 \mathrm{D}$ primate models of intra and interspecific differences. The National Academy of Sciences of the USA, 101: 1147-1152.
17. Harvati K (2003) The Neanderthal taxonomic position models of intraand inter-specific craniofacial variation. J Hum Evol, 44(1): 107-132.

18. Schwartz J, Tattersall I (2002) The human fossil record, vol. 1: Terminology and Cranial Morphology of Genus Homo (Europe).In: New York: Wiley/Liss, pp:132-134.

19. Schwartz J, Tattersall I, (2005) The human fossil record, Cranio dental Morphology of early Hominids (Genera Australopithecus, Paranthropus, Orrorin) and Overview. New York: Wiley/Liss.

20. Tattersall I, Schwartz J (1999) Extict Humans. Boulder: Westview Press CO.

21. Meyer M, Fu Q Aximu-Petri A, Glocke I, Nickel B, et al. (2014) A mitochondrial genome sequence of a hominin from Sima de los Huesos In: Nature, 505(7483): 403-406.

22. Prüfer K, Racimo F, Patterson N, Jay F, Sankararaman S, et al. (2014) The complete genome sequence of a Neanderthal from the Altai Mountains. Nature, 505(7481): 43-49.

23. Kuhlwilm M, Gronau, I, Hubisz J, De Filippo C, Prado-Martinez J, et al. (2016) Ancient gene flow from early modern humans into Eastern Neanderthals. Nature, 530(7591): 429-433.

24. Talon-Hugon, C. 2009. L’Esthétique, Paris, P.U.F., coll. Que sais-je ?, 2004.
This work is licensed under Creative

Commons Attribution 4.0 Licens

DOI: 10.19080/GJAA.2017.01.555563
Your next submission with Juniper Publishers will reach you the below assets

- Quality Editorial service

- Swift Peer Review

- Reprints availability

- E-prints Service

- Manuscript Podcast for convenient understanding

- Global attainment for your research

- Manuscript accessibility in different formats

( Pdf, E-pub, Full Text, Audio)

- Unceasing customer service

Track the below URL for one-step submission https://juniperpublishers.com/online-submission.php 